\title{
Factors Influencing Women's Empowerment in Bangladesh
}

\author{
Mimma Tabassum*, Najma Begum, Mohammad Shohel Rana, Mohammad Omar Faruk, \\ Mohammad Mamun Miah
}

Department of Statistics, Noakhali Science and Technology University, Noakhali, Bangladesh

Email address:

tabassum021521@gmail.com (M. Tabassum)

${ }^{*}$ Corresponding author

\section{To cite this article:}

Mimma Tabassum, Najma Begum, Mohammad Shohel Rana, Mohammad Omar Faruk, Mohammad Mamun Miah. Factors Influencing Women's Empowerment in Bangladesh. Science, Technology \& Public Policy. Vol. 3, No. 1, 2019, pp. 1-7. doi: 10.11648/j.stpp.20190301.11

Received: December 28, 2018; Accepted: January 20, 2019; Published: March 16, 2019

\begin{abstract}
Women especially in developing countries are not empowered in most of fields of their life. They depend on their husband or father in a number of ways. No doubt, education and change of society's attitude towards women is best tool to empower women. Decision making power regarding household, economic, healthcare and women participation in political and social activities can also play positive role to promote awareness to empower women in society. Nowadays, the scenario is changing in Bangladesh and women getting more empower in decision making, earnings and health care. This paper aims to evaluate the factors influencing women's empowerment in Bangladesh. This paper focuses on women empowerment through decision making power at household level, health care, political and social activities. This study reveals that majority of the married women can jointly make decision about their household and economic segment, health care, the participation in political and social activities with their husbands. This paper also shows that urban respondents are relatively more empowered than their rural counterparts and types of place of residence plays a significant role in the women empowerment in Bangladesh. The women who are currently working have more freedom to make decision over their personal, social and political life than the women who are not currently working. This paper recognizes that there is a strong relationship between decision making power and women empowerment.
\end{abstract}

Keywords: Women Empowerment, Factors, Decision Making

\section{Introduction}

Women empowerment has been studied as the prime concern to achieve the goal of gender equality in recent times. Gender equality influences not only the women but also the society as a whole. Nowadays the incorporation of women into the development process and their participation in economic activities along with men, have been gaining importance in many national development plans. The empowerment of women has been characterized by considering a multidimensional issue which can be indicated by education, occupation, discussing about family planning with partners, household decision making, free movement, age at marriage, political representation and legal rights [13]. In 2015, Sustainable Development Goals (SDGs) want to change the course of twenty first century, addressing key challenges like poverty, inequality, violence against women and girls [4]. Women's empowerment is a precondition for this. All the targets of SDG 5 advocate ending all forms of discrimination against all women and girls everywhere, ensuring women's full and effective participation and equal opportunities for leadership at all levels of decision making in political, economic and public life, enhancing the use of technology, particularly in information and communication technology etc. to help women in achieving empower in society.

Empowerment of women refers to decision making power in social, economic and political sphere of life. Empowerment of women is very much essential to achieve sustainable development. It is prerequisite to gender equality and development. Quoting from a UNFPA report, "the state of World Population 1992", the News Letter of Bernard Van Leer Foundation says that there can be no sustainable development without development of women, because it is women who contribute most for the development for children. The process of empowerment should start from our 
own home. Women's position in the household determines women's autonomy in the family. It is worth to examine whether can decide about household matters like buying household assets and jewelries, having access to money, having mobility to go to relatives' house or getting health care facilities [5].

The World Bank study in Bangladesh highlighted that women have had a limited role in the household decisionmaking, limited access and control over household resources (physical and financial assets), low level of individual assets, heavy domestic workloads, restricted mobility and inadequate knowledge and skills that leading to women's vulnerability [6]. The status of women in Bangladesh has been ranked the lowest in the world on the basis of twenty indicators related to health, marriage, children, education, employment and social equality [7]. Evidence from developing countries showed that women's age and family structure were the strongest determinants of women's authority in decision making. Older women and women in nuclear households were more likely than other women to participate in family decisions [8]. In a study [9]on the empowerment of rural Bangladeshi women found that rural women's empowerment can be attained by fostering their level of awareness of ten selected gender issues including under-valuation, educational gap, inheritance of property rights, timing of marriage, practice of dowry, divorce rights, sex bias, birth registration, political awareness and violence against women.

From the overall discussion it is clear that there is no single factor to be the source for empowering women. In order to ascertain the level of women empowerment, there is a need for having precise indicators to measure the status of women empowerment [10]. Various studies mentioned some indicators of women empowerment such as economic contribution, education, decision making power etc. [11]. There is genuine need to identify the indicators of women empowerment. As women's empowerment has a vast field with a countless of indicators, we focus on its prominent dimensions. In this study we consider three indicators of women empowerment such as decision making power on household and economic, healthcare, and women participation in political and social activities. Role of decision making power regarding household, economic, healthcare and women participation in political and social activities in every field of life is vital now a day. Though 47 years have passed since the independence of Bangladesh, the condition of women in Bangladesh leaves much space for improvement. However, women make nearly half of the population, which means there is huge potential to be utilized for socio-economic development of the country. But majority of women of Bangladesh are illiterate or low educated. They depend on their husband or father to fulfill their needs. As result of this dependency, they are bound to follow decisions of their husband or father. They are not allowed to live life according to their wishes. Most of educated women also depend on male members to get permission to fulfill their wishes.
The present study was therefore undertaken to analyze the factors influenced the indicators of women empowerment in Bangladesh. This study is helpful to understand the factors influencing the decision making power of women in the country. This study is also helpful to evaluate role of women in society and policy making, writers and government can get guidelines to analyze their efforts to improve society by promoting the concept of gender equality and women empowerment. They can improve their efforts in the light of results of this study. The study is most important for educationists to consider their role to promote concept of women empowerment through education.

\section{Literature Review}

A study [12] reported that micro credit is contributing to some extent in generating economic activities and participation in family decision making of the rural women and also stated that micro credit program in Bangladesh is developing gender awareness among the women. This study was conceptualized considering three important dimensions of women's empowerment that identifies five principles in which empowerment are achieved including welfare, access equality, awareness raising, participation and control. The results of the study [12] reported that micro credit is contributing to some extent in generating economic activities and participation in family decision making of the rural women.

Empowering Women with Micro Finance: Evidence from Bangladesh examined the effects of men's and women's participation in group based micro credit programs on various indicators of women's empowerment [13]. The results are consistent with the view that women's participation in micro credit program helps to increase women's empowerment. Credit programs lead to women taking a greater role in household decision making, having greater access to financial and economic resources, having greater social networks, having greater bargaining power than their husbands, and having greater freedom of mobility.

According to Makombe, Temba and Kihombothere is an improvement in gender relations and poverty alleviation and there is increased women involvement in decision making, control over household resources and freedom to use their time [14].

\section{Methodology}

The data for this study have been extracted from Bangladesh Demographic and Health Survey 2014 (BDHS 2014), which were conducted by the Ministry of Health and Family Welfare under the authority of the National Institute of Population Research and Training (NIPORT) [15]. In BDHS 2014, a total of 17,989 households were selected, 17,565 were found occupied. Interviews were successfully completed in 17,300, or 99 percent of households. A total of 18,245 ever-married women age 15-49 were identified in these households and 17,863 were interviewed (BDHS 
2014). From 17,863, the respondents who gave clear information regarding our study variables, a sample of 16,830 of them have been included in this study. For the current analysis, firstly frequency distribution has been constructed to observe the percentage of the indicators of women empowerment (WE) and related influencing factors, and then bivariate analysis through Chi-square test have been performed to see the relationships between indicators of women empowerment and the factors considered in this study. To perform the current study Statistical Package for Social Science (SPSS v20) is used.

\subsection{Sample Design}

This study used the data from Bangladesh Demographic and Health Survey 2014 is a nationally representative survey. The survey covers the entire population of the country. The sampling frame is a list of enumeration areas (EAs) of the 2011 Population and Housing Census of the People's Republic of Bangladesh, provided by the Bangladesh Bureau of Statistics (BBS). The Enumerations Area (EA) is considered as a primary sampling unit (PSU) for the survey to have an average of about 120 households. Bangladesh is divided into seven administrative divisions: Barisal, Chittagong, Dhaka, Khulna, Rajshahi, Rangpur, and Sylhet. Each division is divided into zilas, and each zilaintoupazilas. Each urban area in an upazilais divided into wards, which are further subdivided into mohallas. A rural area in an upazilais divided into union parishads(UPs) and, within UPs, into mouzas. These divisions allow the country as a whole to be separated into rural and urban areas (BDHS, 2014). A twostage stratified sampling technique of households is applied for this survey. In the first stage, 600 EAs were selected with probability proportional to the EA size, with 207 EAs and 393 in urban and rural areas respectively A systematic sample of 30 households on average was selected per EA to provide statistically reliable estimates of key demographic and health variables for the country as a whole, for urban and rural areas separately, and for each of the seven divisions in second stage of sampling. With this design, the survey selected 18,000 residential households, which were expected to result in completed interviews with about 18,000 ever-married women (BDHS 2014) [12].

\subsection{Selected Indicators}

In this study three indicators of women empowerment is considered, the variable in BDHS 2014 "Women Decision Making Power on Large Household Purchase" considered as a "Household \& Economic" decision making indicator of women empowerment, the variable "Person who Usually Decides on Respondent's Health Care" is considered as a "Health Care" decision making indicator and the final variable "Person who Usually Decides on Visits to Relatives or Different Social Organization" is considered as a "Women Participation in Political and Social Activities" decision making indicator of women empowerment. The influencing factors of women empowerment considered in this study are stated as follows: Type of place of residence, Respondent educational level, Husband/partner's education level, Division, Sex of household head, Respondent currently working, Beating justified if wife goes out without telling husband, Beating justified if wife neglects the children, Beating justified if wife argues with husband, Beating justified if wife refuses to have sex with husband, Beating justified if wife burns the food, Respondent current age, Religion, Number of household members, Access to mass media, Belongs to any organization, Husband Occupation, Current Marital Status, Socio Economic status.

\section{Result and Discussion}

From the frequency distribution analysis it is observed that $17 \%$ of the respondents are from Dhaka division followed by Chittagong division which is $16 \%$. The most of the respondents in this analysis are from rural area followed by urban area and there percentages are $62 \%$ and $38 \%$ respectively. Frequency distribution reveals that $22 \%$ of the respondents are illiterate, $30 \%$ have primary education, $39 \%$ completed their secondary education and only $10 \%$ of the ever married women in Bangladesh are higher educated. In Bangladesh $90 \%$ of the household head are male compared to $10 \%$ of their female counterparts. When the respondents are asked about their husband education it is found that $27 \%$ of their husbands are illiterate, primary educated and secondary educated respectively and only $15 \%$ are higher educated. The frequency distribution shows that only $30 \%$ of the married women are currently working compared to $70 \%$ of their nonworking counterparts. In case of women empowerment "Health Care" indicator, the result shows that only $15 \%$ of the women can decide about their own health care whereas $48 \%$ of them jointly decide to take health care with their husbands and $30 \%$ of the women depend of their husbands about their health care. Another important women empowerment indicator is "Household and Economic" decision making indicator. In case of this indicator it is observe that $9 \%$ of the women take decision alone about their large household purchase, $50 \%$ of the women jointly take decision with their husbands on their large household purchase and $29 \%$ of the women depend on their husbands about large household purchase. The frequency distribution of "Women Participation in Political and Social Activities" indicator shows that $10 \%$ of the women can take decision to go outside home and participate in political and social activities without their husbands permission, $50 \%$ of the women jointly take decision to participate in political and social activities with their husbands. From the analysis, it is observed that only $15 \%$ of the women are justified of beating if wife goes out without telling husband compared to $85 \%$ of not beating counterparts. It is also observed that $15 \%$ of the women justified of beating if she neglect the children. A slide rise of beating justified in case of wife argues with husband and it is found $20 \%$. Only $7 \%$ of the women beating justified if she refuse to have sex with husband and $4 \%$ wife beating justified if wife burns food. In our study $15 \%$ of respondents 
are age between 15 and $20,37 \%$ of the respondents are age between 20 to $30,28 \%$ of the respondents are age between 30 to 40 and $18 \%$ of the ever married women are age above 40 . From the frequency distribution, we see that $90 \%$ of the respondents in our study are Muslim and only $10 \%$ from other religion. In Bangladesh $64 \%$ of the women have access to mass media compared to $36 \%$ of their counterparts who have not any access to mass media. It is observed from the frequency distribution that only $25 \%$ of the women belong to any organization whereas $75 \%$ of the women do not have any involvement with any organization. In the present study it is found that $94 \%$ of the married women living with their husband and only $6 \%$ of the ever married women are separated.

The bivariate analysis is performed to see if there is any association between the indicator of women empowerment and influencing factors considered in this study. From the bivariate analysis it is observed that the factor "Type of Place of Residence" has a significant association on "Women Household \& Economic Decision Making Power" indicator of women empowerment.

Table 1. Association between types of place of residence and household \& economic decision making power.

\begin{tabular}{llll}
\hline Chi-Square Tests & Value & df & Asymp. Sig. (2-sided) \\
\hline Pearson Chi-Square & $1.221 \mathrm{E} 2^{\mathrm{a}}$ & 4 & .000 \\
Likelihood Ratio & 122.147 & 4 & .000 \\
Linear-by-Linear Association & 110.997 & 1 & .000 \\
\hline
\end{tabular}

0 cells $(.0 \%)$ have expected count less than 5. The minimum expected count is 15.00 .

Table 1 shows the value of Pearson Chi-Square test which is 0.000 , that means that the test is highly significant and there is a strong association between "Types of Place of Residence" and "Women Household \& Economic Decision Making Power" indicator. Similar tables for other two women empowerment indicator with "Types of Place of
Residence" show that the mentioned factor is significantly associated with "Women Health Care Decision Making Power" and "Women Participation in Political and Social Activities Decision Making Power" indicator of women empowerment.

Table 2. Cross tabulation of types of place of residence and household \& economic decision making power.

\begin{tabular}{|c|c|c|c|c|c|c|c|}
\hline \multirow{2}{*}{\multicolumn{2}{|c|}{ Type of Place of Residence }} & \multicolumn{5}{|c|}{ Household \& Economic Decision Maker } & \multirow[b]{2}{*}{ Total } \\
\hline & & Respondent alone & $\begin{array}{l}\text { Respondent and } \\
\text { husband/partner }\end{array}$ & $\begin{array}{l}\text { Husband/ } \\
\text { partner alone }\end{array}$ & Someone else & Other & \\
\hline \multirow{2}{*}{ Urban } & Frequency & 630 & 3104 & 1475 & 519 & 11 & 5739 \\
\hline & Percentage & $11.0 \%$ & $54.1 \%$ & $25.7 \%$ & $9.0 \%$ & $.2 \%$ & $100.0 \%$ \\
\hline \multirow{2}{*}{ Rural } & Frequency & 874 & 5440 & 3532 & 1211 & 33 & 11090 \\
\hline & Percentage & $7.9 \%$ & $49.1 \%$ & $31.8 \%$ & $10.9 \%$ & $.3 \%$ & $100.0 \%$ \\
\hline \multirow{2}{*}{ Total } & Frequency & 1504 & 8544 & 5007 & 1730 & 44 & 16829 \\
\hline & Percentage & $8.9 \%$ & $50.8 \%$ & $29.8 \%$ & $10.3 \%$ & $.3 \%$ & $100.0 \%$ \\
\hline
\end{tabular}

Table 2 shows in case of "Household \& Economic Decision Making Power" only $9 \%$ of the urban women can make decision alone compared to $7.9 \%$ of their rural counterpart. Table 2 also shows that $54 \%$ of the urban women jointly make decision with their husbands compared to $49 \%$ of their rural counterparts. Similar table for "Type of Place of Residence" and "Health Care Decision Making Power" indicator show that $17 \%$ of the urban respondents can make decision alone on their own health care whereas only $14 \%$ rural respondents can make decision on their health care related decision making. The table for "Type of Place of Residence" and "Decision Making Power on Participating Political and Social Activities" shows that $13 \%$ of the urban women can make decision alone over their participation in politics and social activities compared to $10 \%$ of their rural counterparts.

Table 3. Association betweeneducational status and household \& economic decision making power.

\begin{tabular}{llll}
\hline Chi-Square Tests & Value & df & Asymp. Sig. (2-sided) \\
\hline Pearson Chi-Square & $4.208 \mathrm{E2}{ }^{\mathrm{a}}$ & 12 & .000 \\
Likelihood Ratio & 444.656 & 12 & .000 \\
Linear-by-Linear Association & 33.864 & 1 & .000 \\
\hline
\end{tabular}

a. 1 cells $(5.0 \%)$ have expected count less than 5 . The minimum expected count is 4.37 .

Table 3 reveals that educational status is highly significantly associated with the household \& economic decision making power indicator of women empowerment. Similar tables for other two indicators show significant association between "Educational Status" and "Health Care Decision Making Power" and "Involvement in Social and Political Activities" respectively. 
Table 4. Cross tabulation of educational status and household \& economic decision making power.

\begin{tabular}{|c|c|c|c|c|c|c|c|}
\hline \multicolumn{7}{|c|}{ Household \& Economic Decision Maker } & \multirow[b]{2}{*}{ Total } \\
\hline Highest ed & onal level & $\begin{array}{l}\text { Respondent } \\
\text { alone }\end{array}$ & $\begin{array}{l}\text { Respondent and } \\
\text { husband/partner }\end{array}$ & Husband/partner alone & $\begin{array}{l}\text { Someone } \\
\text { else }\end{array}$ & Other & \\
\hline \multirow{2}{*}{ Illiterate } & Frequency & 365 & 1923 & 1249 & 176 & 2 & 3715 \\
\hline & Percentage & $9.8 \%$ & $51.8 \%$ & $33.6 \%$ & $4.7 \%$ & $.1 \%$ & $100.0 \%$ \\
\hline \multirow{2}{*}{ Primary } & Frequency & 463 & 2473 & 1598 & 370 & 10 & 4914 \\
\hline & Percentage & $9.4 \%$ & $50.3 \%$ & $32.5 \%$ & $7.5 \%$ & $.2 \%$ & $100.0 \%$ \\
\hline \multirow{2}{*}{ Secondary } & Frequency & 546 & 3191 & 1828 & 939 & 23 & 6527 \\
\hline & Percentage & $8.4 \%$ & $48.9 \%$ & $28.0 \%$ & $14.4 \%$ & $.4 \%$ & $100.0 \%$ \\
\hline \multirow{2}{*}{ Higher } & Frequency & 130 & 957 & 332 & 245 & 9 & 1673 \\
\hline & Percentage & $7.8 \%$ & $57.2 \%$ & $19.8 \%$ & $14.6 \%$ & $.5 \%$ & $100.0 \%$ \\
\hline \multirow{2}{*}{ Total } & Frequency & 1504 & 8544 & 5007 & 1730 & 44 & 16829 \\
\hline & Percentage & $8.9 \%$ & $50.8 \%$ & $29.8 \%$ & $10.3 \%$ & $.3 \%$ & $100.0 \%$ \\
\hline
\end{tabular}

Table 4 shows that the respondents who are not educated or illiterate $9.8 \%$ of them can make decision alone on household \& economic decision making. On the other hand we see that $9.4 \%$ of the respondents who are primary educated and $8.4 \%$ of the respondents who are secondary educated can make decision alone over household \& economic decision making and $7.8 \%$ of the respondents who are higher educated can make decision alone over the important women empowerment indicator. This result is not quite good; it should be like that the higher educated women can make decision alone over household \& economic empowerment more than the respondents who are illiterate. Similar result is found in rest two indicator of women empowerment.

Table 5. Association betweensex of household head and health care related decision making power.

\begin{tabular}{llll}
\hline Chi-Square Tests & Value & df & Asymp. Sig. (2-sided) \\
\hline Pearson Chi-Square & $1.155 E 3^{\text {a }}$ & 4 & .000 \\
Likelihood Ratio & 904.422 & 4 & .000 \\
Linear-by-Linear Association & 288.427 & 1 & .000 \\
\hline
\end{tabular}

1 cell $(10.0 \%)$ has expected count less than 5 . The minimum expected count is 2.72 .

Table 5 shows that the value of Chi-Square is 0.000 which means that there is significant association between "Sex of Household Head" and "Health Care related Decision Making Power". The similar tables for other two indicators of women empowerment describe that "Sex of Household Head" is significantly associated with "Economic Decision Making Power" and "Participation in Political and Social Activities" respectively.

Table 6. Cross Tabulation of sex of household head and health care related decision making power.

\begin{tabular}{|c|c|c|c|c|c|c|c|}
\hline \multirow{2}{*}{\multicolumn{2}{|c|}{ Sex of Household Head }} & \multicolumn{5}{|c|}{ Health Care Related Decision Maker } & \multirow[b]{2}{*}{ Total } \\
\hline & & $\begin{array}{l}\text { Respondent } \\
\text { alone }\end{array}$ & $\begin{array}{l}\text { Respondent and } \\
\text { husband/partner }\end{array}$ & Husband/partner alone & $\begin{array}{l}\text { Someone } \\
\text { else }\end{array}$ & Other & \\
\hline \multirow{2}{*}{ Male } & Frequency & 1861 & 7628 & 4938 & 851 & 24 & 15302 \\
\hline & Percentage & $12.2 \%$ & $49.8 \%$ & $32.3 \%$ & $5.6 \%$ & $.2 \%$ & $100.0 \%$ \\
\hline \multirow{2}{*}{ Female } & Frequency & 669 & 486 & 245 & 121 & 6 & 1527 \\
\hline & Percentage & $43.8 \%$ & $31.8 \%$ & $16.0 \%$ & $7.9 \%$ & $.4 \%$ & $100.0 \%$ \\
\hline Total & Percentage & $15.0 \%$ & $48.2 \%$ & $30.8 \%$ & $5.8 \%$ & $.2 \%$ & $100.0 \%$ \\
\hline
\end{tabular}

Table 6 shows that the respondents whose household head are male only $12 \%$ of them can make decision herself on their health care whereas $43.8 \%$ of the respondents whose household head are female they can herself make decision over their health care. From the study it is observed that the respondents whose household head are male $49.8 \%$ of them can jointly make decision with their husband on their health care whereas only $31 \%$ jointly make decision when household head are female.

From the bivariate analysis it is observed that the administrative division in Bangladesh is highly significantly associated with all three indicator of women empowerment. From the bivariate table it is found that $19.7 \%$ of the female respondents in Chittagong decide alone about the health care followed by $17.9 \%$ of the respondents in Khulna division can make decision alone about their health care. The result show that $12.7 \%$ of the respondents in Chittagong division can make decision alone followed by $11.3 \%$ of the Khulna division about household and economic indicator of women empowerment. The administrative division is highly significantly associated with the women health care related indicator and the result show that the respondents of Chittagong division is more empowered than other administrative division in Bangladesh.

Husband education is found to be a most important factor that is significantly associated with the women "Health Care" 
indicator. The result shows that the respondents whose husbands are higher educated are free to make decision about their own health care. Husband education is also found to be significantly associate with the women empowerment indicator "Household and Economic Decision Making Power". The Chi-Square table shows that husband education is significantly associated with another women empowerment indicator "Women Participation in Political and Social Activities" and the result describe that the respondents whose husbands are higher educated have more involvement in political and social activities.

Table 7. Association between respondents currently working and health care related decision making power.

\begin{tabular}{llll}
\hline Chi-Square Tests & Value & df & Asymp. Sig. (2-sided) \\
\hline Pearson Chi-Square & $1.646 \mathrm{E} 2^{\mathrm{a}}$ & 4 & .000 \\
Likelihood Ratio & 179.077 & 4 & .000 \\
Linear-by-Linear Association & 137.331 & 1 & .000 \\
\hline
\end{tabular}

0 cell $(.0 \%)$ has expected count less than 5 . The minimum expected count is 9.07 .

From table 7 we observe that there is a significant relationship between "Respondents Working Status" and women empowerment indicator "Health Care Decision Making Power". The result from the table 8 shows that the respondents who are currently working can decide more about their health care related context than the respondents who are not currently working.

Table 8. Cross tabulation of respondents working status and health care related decision making power.

\begin{tabular}{|c|c|c|c|c|c|c|c|}
\hline \multirow{2}{*}{\multicolumn{2}{|c|}{ Respondent Currently Working }} & \multicolumn{5}{|c|}{ Health Care Related Decision Maker } & \multirow[b]{2}{*}{ Total } \\
\hline & & $\begin{array}{l}\text { Respondent } \\
\text { alone }\end{array}$ & $\begin{array}{l}\text { Respondent and } \\
\text { husband/partner }\end{array}$ & Husband/partner alone & Someone else & Other & \\
\hline \multirow{2}{*}{ No } & Frequency & 1641 & 5491 & 3764 & 813 & 29 & 11738 \\
\hline & Percentage & $14.0 \%$ & $46.8 \%$ & $32.1 \%$ & $6.9 \%$ & $.2 \%$ & $100.0 \%$ \\
\hline \multirow{2}{*}{ Yes } & Frequency & 888 & 2621 & 1417 & 159 & 1 & 5086 \\
\hline & Percentage & $17.5 \%$ & $51.5 \%$ & $27.9 \%$ & $3.1 \%$ & $.0 \%$ & $100.0 \%$ \\
\hline \multirow{2}{*}{ Total } & Frequency & 2529 & 8112 & 5181 & 972 & 30 & 16824 \\
\hline & Percentage & $15.0 \%$ & $48.2 \%$ & $30.8 \%$ & $5.8 \%$ & $.2 \%$ & $100.0 \%$ \\
\hline
\end{tabular}

In Table 8 Respondent currently working status is found to be a most significant factor that is highly significantly associated with the other two indicator of women empowerment. In case of household and economic decision making indicator the respondents who are currently working have more freedom to decide their large household purchase. Same result is found when we study the women participation in political and social activities. Here also the respondents who are currently working have more freedom to decide about the participation in political and economic decision making power than the respondents who are not currently working.

Respondent current age is found to be a significant factor that associated with the indicators of women empowerment. The bivariate table shows that the respondents age between 30 and 40 are more empowered followed by the respondent's age above 40. Access to mass media is significantly associated with the indicators of women empowerment and the bivariate result shows that the respondents who have access to mass media have more freedom than the respondents who do not have any access to mass media. The variable "Respondents belong to Any Organization" is found to have a significant association with the indicator of women empowerment. The variable "Current Marital Status" is not significantly associated with the indicators of women empowerment. Husband occupation is also found to be a significant factor associated with the indicators of women empowerment.

\section{Conclusion}

From the above analysis it can be concluded that there is a positive relationship between decision making power regarding household, economic, healthcare and women participation in political and social activities and women empowerment. The degree of women's decision making power is not the same over the different aspects of life and situation. In the analysis it is observed that majority of the married women can jointly make decision about their household and economic segment with their husbands. Women have sole authority to decide about cooking and have access to money for this purpose, but can rarely purchase household assets and jewelry of its own. Further women have freedom to decide about their healthcare and visits to their relative's house. It is also found that $50 \%$ of the women can make decision along with their husbands about the participation in political and social activities. Further, it is different between rural and urban areas and the women education and occupation level. The women who are engaged in earning activities are more empowered and have more freedom to make decision over their personal, family, social and political life than the women who are not working. So it needs to take proper initiatives so that every woman should be participated in income generating activities even those are merely engaged as housewife should be considered as earning person in the family and then they will be 
approached into the way to make them empowerment properly. Access to mass media is significantly associated with the indicators of women empowerment and the women who have access to mass media are more empowered than the respondents who have no access.

So in this situation the change of attitude of women and men is very important to empower women by giving decision making power regarding household, economic, healthcare and women participation in political and social activities to them. The family relations training are needed to the rural people and which is not only for women participants but to their male family members also. These gender workshops and training programs will bring women and men together to discuss responsibilities and decision making regarding household, economic, healthcare and women participation in political and social activities. If only the attitude of society towards women is being changed women could be empowered. Further, microfinance programs should be considered in the rural areas which lead to decision making power of women regarding household, economic, healthcare and women participation in political and social activities.

\section{References}

[1] Dixon-Mueller RB. Rural women at work: Strategies for development in South Asia. RFF Press; 2013 Nov 26.

[2] ALSAAWI M, ADAMCHAK DJ. Women's status, fertility and contraceptive use in Kazakhstan. Genus. 2000 Jan 1:99113.

[3] Al-Riyami AA, Afifi M. Determinants of women's fertility in Oman. Saudi medical journal. 2003;24(7):748-53.

[4] United Nation Development Programme (UNDP) (2016). Sustainable Development Goals (SDGs).
[5] Kawachi I, Kennedy BP, Gupta V, Prothrow-Stith D. Women's status and the health of women and men: a view from the States. Social Science \& Medicine. 1999 Jan 1;48(1):21-32.

[6] Sebstad J, Cohen M. Microfinance, Risk Management and Poverty: Synthesis Study. Consultative Group to Assist the Poorest (. CGAP), World Bank; 2001.

[7] NCBP (2000). Gender Equality, Development and Peace for the Twenty-first Century. NGO Committee on Beijing plus Five in Bangladesh, Dhaka. Women for Women - A Research and Study Group.

[8] Sathar ZA, Kazi S. Women's autonomy in the context of rural Pakistan. The Pakistan Development Review. 2000 Jul 1:89110 .

[9] Parveen S. Gender awareness of rural women in Bangladesh. Journal of International Women's Studies. 2007;9(1):253-69.

[10] Akter S, Chanda SK, Al Mamum A, Razu SR. Innovative Research.

[11] Pitt MM, Khandker SR. Household and intrahousehold impact of the Grameen Bank and similar targeted credit programs in Bangladesh. The World Bank; 1996 Jun 1.

[12] Hoque M, Itohara Y. Women empowerment through participation in micro-credit programme: A case study from Bangladesh. Journal of Social Sciences. 2009;5(3):244-50.

[13] Pitt MM, Khandker SR, Cartwright J. Empowering women with micro finance: Evidence from Bangladesh. Economic Development and Cultural Change. 2006 Jul;54(4):791-831.

[14] Makombe IA, Temba EI, Kihombo AR. Credit schemes and women's empowerment for poverty alleviation: the case of Tanga Region, Tanzania.

[15] NIPORT (2014). National Institute of Population Research and Training (NIPORT), mitra and Associates (MA), and ORC Macro (ORCM). Bangladesh Demographic and Health survey 2014. Dhaka, Bangladesh and Calverton, Maryland, USA. 